\title{
Variable executive remuneration and company performance: Insights from the Johannesburg Stock Exchange, South Africa
}

\begin{tabular}{|c|c|}
\hline \multicolumn{2}{|c|}{$\begin{array}{l}\text { Authors: } \\
\text { Minal Naik }^{1} \text { (D) } \\
\text { Nirupa Padia }{ }^{1} \\
\text { Chris W. Callaghan } \\
\end{array}$} \\
\hline \multirow{2}{*}{\multicolumn{2}{|c|}{$\begin{array}{l}\text { Affiliations: } \\
{ }^{1} \text { School of Accountancy, } \\
\text { Faculty of Commerce, Law } \\
\text { and Management, University } \\
\text { of the Witwatersrand, } \\
\text { Johannesburg, South Africa }\end{array}$}} \\
\hline & \\
\hline \multicolumn{2}{|c|}{$\begin{array}{l}{ }^{2} \text { School of Economic and } \\
\text { Business Sciences, University } \\
\text { of the Witwatersrand, } \\
\text { Johannesburg, South Africa }\end{array}$} \\
\hline \multicolumn{2}{|c|}{$\begin{array}{l}{ }^{3} \text { Knowledge and } \\
\text { Information Economics/ } \\
\text { Human Resources Research } \\
\text { Agency (KIEHRA), University } \\
\text { of the Witwatersrand, } \\
\text { Johannesburg, South Africa }\end{array}$} \\
\hline \multicolumn{2}{|c|}{$\begin{array}{l}\text { Corresponding author: } \\
\text { Chris Callaghan, } \\
\text { chris.callaghan@wits.ac.za }\end{array}$} \\
\hline \multicolumn{2}{|c|}{$\begin{array}{l}\text { Dates: } \\
\text { Received: } 28 \text { Apr. } 2019 \\
\text { Accepted: } 31 \text { Jan. } 2020 \\
\text { Published: } 19 \text { Mar. } 2020\end{array}$} \\
\hline \multicolumn{2}{|c|}{$\begin{array}{l}\text { How to cite this article: } \\
\text { Naik, M., Padia, N. \& } \\
\text { Callaghan, C.W., 2020, } \\
\text { 'Variable executive } \\
\text { remuneration and company } \\
\text { performance: Insights from } \\
\text { the Johannesburg Stock } \\
\text { Exchange, South Africa', Acta } \\
\text { Commercii 20(1), a790. } \\
\text { https://doi.org/10.4102/ } \\
\text { ac.v20i1.790 }\end{array}$} \\
\hline \multicolumn{2}{|c|}{$\begin{array}{l}\text { Copyright: } \\
\text { (C) 2020. The Authors. } \\
\text { Licensee: AOSIS. This work } \\
\text { is licensed under the } \\
\text { Creative Commons } \\
\text { Attribution License. }\end{array}$} \\
\hline \multicolumn{2}{|l|}{ Read online: } \\
\hline 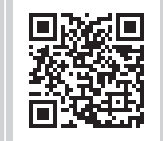 & $\begin{array}{l}\text { Scan this QR } \\
\text { code with your } \\
\text { smart phone or } \\
\text { mobile device } \\
\text { to read online. }\end{array}$ \\
\hline
\end{tabular}

Orientation: Agency theory predicts that agency relationships are subject to the principalagent problem. Other theories also suggest that executives may tend to maximise sales revenues, or expand their spans of influence through growth, at the expense of the net value of the firm or its profitability.

Research purpose: The purpose of this study is to test which forms of company performance are associated with higher executive variable pay ratios or determine the proportion of variable director remuneration to total remuneration.

Motivation for the study: The extent to which variable remuneration is associated with different types of firm performance is unclear.

Research design, approach and method: This study applies a simple panel regression model to test the extent to which the variable ratio of total director remuneration contributes differently to increases in firm revenue, total assets, return on assets, or measures of Tobin's Q. These relationships are tested for listed companies on South Africa's Johannesburg Stock Exchange, South Africa, for the years 2011-2014.

Main findings: Variable remuneration is found to be negatively and strongly related to total revenue and negatively and weakly related to total assets (the gross measures of performance). In contrast, variable remuneration is weakly and positively related to Tobin's Q, a measure which better reflects the interests of shareholders than gross measures.

Practical/managerial implications: Firms in this context should seek to strengthen the linkages between variable remuneration and forms of performance that reflect the interests of stakeholders.

Contribution/value-add: In the wake of global and local governance failures, this study suggests that the use of the variable component of executive remuneration might be helpful in aligning stakeholder interests. Further research might seek to better understand the causal mechanisms that underlie these findings.

Keywords: executive remuneration; firm performance; corporate governance; human resource management; South Africa.

\section{Introduction}

Long-standing theory (see, for example, Baumol 1959; Marris 1964; Williamson 1963) predicts that executives tend to maximise sales revenues, subject to a minimum profit constraint, or may seek to enlarge their spans of influence through growth, rather than maximising the net value of the firm or its profitability. Similarly, agency theory (Jensen \& Meckling 1976) predicts that the interests of executives and firm owners are not necessarily aligned, and that executive remuneration, and more specifically variable remuneration, should be utilised as a tool to align these interests. Knowledge of the effectiveness of variable remuneration - remuneration that is contingent on performance - hinges therefore on whether there is a positive relationship between variable remuneration as a ratio of total remuneration and the value of the firm measures, such as Tobin's Q, and a negative relationship with revenue maximisation measures, such as gross revenue, as well as span of influence maximisation measures, such as total assets (TAs).

Issues of very high executive remuneration in the face of serious problems in companies (Colvin 2008) have raised questions about the extent company directors and executives are seen as selfinterested actors, pursuing their own ends at the expense of stakeholders (McConvill 2005; 
Nelson, Gallery \& Reza 2011; Scholtz \& Smit 2012). On the basis of their study on earnings management, Pududu and De Villiers (2016:18) concluded that there is a 'possibility that investors and analysts in South Africa may be fixated on other performance indicators, such as revenue and headline earnings per share, rather than on earnings (profits)'. The focus here, however, is delimited to the remuneration of executive directors. Remuneration of directors has increasingly become one of the most debated topics in the corporate governance arena, reflecting growing tensions between directors and shareholders (Deloitte 2014). These debates are especially salient with regard to publicly traded companies (Fernandes 2005). Given seminal theoretical predictions that the interests of company directors and shareholders can be aligned through the use of variable remuneration strategies, the objective of this research is to test the theoretical prediction that a higher variable component of remuneration is effective at reducing the focus on revenue maximisation at the expense of the value of the firm. Companies listed on the Johannesburg Stock Exchange (JSE) across the years 2011-2014 were the subjects of this analysis.

There are certain reasons as to why the relationships between executive remuneration and executive performance are particularly important in this context and at this point in time. South Africa has emerged from the recent 2008 economic downturn, which has been described as the worst financial crisis since the Great Depression of the 1930s (Amadeo 2017). Previously rated top in the world on the World Economic Forum's (WEF) index of the quality of auditing and reporting standards, in the 2017-2018 report, the country fell to the 30th position, also dropping 14 positions overall from the previous report (WEF 2018). The following summary provides contextual insight (WEF 2018) into the country's economic conditions:

South Africa's economy is nearly at a standstill, with GDP growth forecast at just 1.0 percent in 2017 and 1.2 percent in 2019 - hit by persistently low international demand for its commodities, while its unemployment rate is currently estimated above 25 percent and rising. Political uncertainty in 2017 has decreased the confidence of South African business leaders: although relatively good in the African context, the country's institutional environment (76th), financial markets (44th), and goods market efficiency (54th) are all rated as weaker than last year. (p. 34)

The recent downturn in the country's corporate governance standing has occurred at the same time as the country faces other economic and political challenges. Research into executive remuneration may therefore be particularly important at this time. In the wake of the global economic downturn, media attention has been increasingly focussed on ongoing increases in executive remuneration (Nelson et al. 2011; Otten 2007; Sapp 2007), particularly when seemingly unrelated to company performance. Similarly, research interest in this topic has also grown, although primarily in the United States, Canada, the United Kingdom and Europe (De Wet 2012), but the developing country research has seemingly not kept pace with the developed country research on executive remuneration structures and its consequences for firm performance.

In light of these issues and the paucity of research on these issues in the South African context, this study seeks to test theory predicting relationships between variable executive director remuneration and company performance in the South African context of publicly traded companies, using data drawn from South African companies listed on the JSE, and performance measures such as Tobin's $Q$, return on assets (ROA), TA and total revenue. This research is taken to be important, for the following reasons.

Firstly, the South African context has not escaped the experience of high-profile corporate failures, which include cases such as LeisureNet, Regal Treasury Bank Limited and Saambou Limited (Sanda, Mikailu \& Garba 2008), and general agreement exists that when companies are well governed, superior performance is more likely to result (Kyereboah-Coleman \& Biekpe 2005). While most research into executive remuneration typically focusses on developed world contexts (De Wet 2012), the costs of corporate failure and poor executive performance are arguably as, or even more, acute in a developing country context of high unemployment and scarce resources. Lack of knowledge of localised influences around executive remuneration and performance can impose a cost that is borne disproportionately by the most vulnerable stakeholders.

Secondly, the debate on inflated sums being paid to chief executive officers (CEOs) is not new, as shareholders expect executive directors who are paid high salaries to perform, prove their worth and grow the company (Tariq 2010), and there have been several steps taken to reduce the widening gap between executive director remuneration and company performance. These steps include the introduction of the Greenbury report in 1995 in the United Kingdom and the Sarbanes-Oxley Act of 2002 in the United States (Tariq 2010). Scholtz and Smit (2012) therefore suggested that the payperformance link may have become even stronger after the introduction of King III report in 2009 in South Africa, as the report requires companies to adopt remuneration policies over the long term and increase transparency in how executive directors are remunerated. Knowledge of variable pay-performance linkages in the wake of King III report is therefore considered particularly important in this context, to understand the extent to which corporate governance has been responsive to this kind of intervention. This work therefore builds on research such as that by De Wet (2012) and Scholtz and Smit (2012) by including options in the estimation of the impact of variable remuneration on company gross performance measures (such as changes in revenue and TAs) versus net performance measures (such as Tobin's $Q$ and ROAs).

The article proceeds as follows. Firstly, literature related to the theoretical framework of the research is introduced. Next, this study is placed in relation to previous research, including 
other studies conducted within the South African context. After this, the methods of this study are outlined. The results are then reported and discussed. This article concludes with a discussion of the implications of the findings and recommendations for further research.

\section{Theory and hypotheses}

Literature reflects a growing interest in the role of executive remuneration committees (Main \& Johnston 2012) and the extent to which performance remuneration schemes are in the interests of shareholders (Forbes \& Watson 2012). Similarly, the influence on executive remuneration of differences in regulatory regimes (Ingham \& Thompson 2012) highlights the importance of contextual influences in shaping the boundary conditions, or predictions of theory related to executive remuneration. Indeed, in recent years, few issues have elicited as much ongoing controversy worldwide as executive remuneration (De Wet 2012; Otten 2007). Global financial crises (GFCs) have borne witness to several notable collapses in the corporate realm (Nelson et al. 2011), such as US insurance companies, Fannie Mae, WorldCom and Enron, to name a few, each associated with extremely high executive remuneration in spite their poor performance (McConvill 2005). Of particular importance is the way compensation package structures can determine executive incentives and how this in turn can influence how companies are operated (Sapp 2007), reflecting the importance of corporate governance in its influence on executive remuneration. However, also of importance are recent findings in the South African context that the relationships between corporate governance and performance can differ by industry (Tshipa et al. 2018), demonstrating the heterogeneity present in these relationships.

Corporate governance has been defined narrowly as the ways in which the suppliers of finance to corporations assure themselves of receiving a return on their investment (Shleifer \& Vishny 1997), or more broadly as a process that aims to allocate corporate resources in a manner that maximises value for all stakeholders, namely, employees, customers, suppliers, the environment and the community at large as well as the set of processes, customs, policies, laws and institutions affecting the way in which a company is directed, administered or controlled (Maradi, Navi \& Dasar 2015). Sheng (2000) defined corporate governance as a means to ensure the accountability of certain individuals in an organisation through mechanisms that endeavour to reduce or eliminate the principal-agent problem. The latter notion explicitly links corporate governance to agency theory, acknowledging Jensen and Meckling's (1976) argument that one of the key objectives of modern corporate governance is addressing agency problems. The following sections provide an overview of agency theory as well as literature on director remuneration and firm performance.

The relationship between the way in which executives are remunerated and whether remuneration practice and levels are in line with company performance has thus become a controversial topic worldwide, including in South Africa (Bradley 2013). According to De Wet (2012), directors of top South African companies typically receive bonuses even when the profits are decreasing by substantial margins. However, with the advent of the King III report in 2009, which requires that companies adopt remuneration policies over the long term, it might become possible to bridge this gap (IOD 2009; Scholtz \& Smit 2012). Knowledge of the extent to which variable executive remuneration is linked to net performance measures such as Tobin's $Q$ and ROAs rather than gross measures such as revenues or TAs is lacking in the literature at this time, and this study seeks to address this deficiency in the literature through a study of these effects across the years 2011-2014, which correspond to a post-King III report era in this context. In order to understand the consequences of differences in the relationships between executive remuneration and company performance, it is important to frame these relationships in terms of theory. Doing so provides the theoretical frame of this research and allows for the testing of theory. This study is therefore theoretically grounded in agency theory, which is introduced as follows.

An agency relationship, as defined by Jensen and Meckling (1976), is:

$[A]$ contract under which one or more persons (the principal(s)) engage another person (the agent) to perform some service on their behalf which involves delegating some decision making authority to the agent. (p. 5)

Here managers (who are utility maximisers) might be incentivised to indulge in opportunistic behaviour that serves their own interests and not necessarily those of shareholders. In terms of the global literature, results of tests of the relationships between executive remuneration and firm performance are mixed. Gregg, Jewell and Tonks (2010) found evidence of a highly positive relationship between executive remuneration and company size but little evidence of a relationship between executive remuneration and other measures of company performance. Nelson et al. (2011) found that several companies reduced their executive remuneration as a result of poor company performance during and after the GFC. Conyon (1997) found executive pay to be directly proportional to current shareholder returns but not to pre-dated returns. In their study of the UK Cadbury Commission, Girma, Thompson and Wright (2003) found that it was difficult to establish any relationship between company performance and executive remuneration. Similarly, McConvill (2005) found that the link between executive pay and performance to be questionable. On the other hand, Merhebi et al. (2006) found that executive pay was directly linked to company performance in companies in Australia.

The South African literature also offers mixed results. Given that this study attempts to analyse relationships between executive director remuneration and company performance for companies listed on the JSE, this work builds on previous 
research in this area. Similar studies, however, such as those by Bradley (2013), De Wet (2012) and Scholtz and Smit (2012) reported contradictory findings. Bradley (2013) found no correlation between CEO compensation and company performance, suggesting that attempts to align the interests of managers and shareholders through executive pay in South Africa may have so far been unsuccessful. Bradley (2013) also suggested that attempts to use executive pay as a method of mitigating the conflict of interest that exists between managers and shareholders may require changes to typical pay structures or the consideration of alternative means of remuneration. On the other hand, Scholtz and Smit (2012) found evidence of a strong relationship between executive remuneration and certain company performance indicators, such as the TAs, turnover and share price for companies listed on the AltX. Similarly, De Wet (2012) found evidence of a significant relationship between executive remuneration and company performance for JSE-listed companies as compared with those listed in the United States. However, in a context in which, according to Theku (2014), the debate on executive remuneration and company performance in South Africa is dominated by widening income inequality between executives and ordinary workers, the question of whether remuneration is being used to ensure shareholder value at this time is particularly salient. Given the discussion of this body of literature, the following hypothesis is derived:

Hypothesis 1. Remuneration will be significantly associated with short-term measures of performance.

For the purposes of testing this hypothesis, short-term measures of performance are taken to include revenue and TAs, as these do not capture longer term benefits to the firm, such as profitability, the latter which has implications for sustainability. Longer term measures therefore relate to sustainability and are taken here to include Tobin's Q (defined as the market value of the firm divided by its replacement value), and ROAs. Also derived from the discussions above is Hypothesis 2:

Hypothesis 2. The variable executive remuneration ratio is positively and significantly associated with firm performance.

The variable executive remuneration ratio is a measure of variable remuneration (comprising benefits, annual bonuses and share options) divided by total remuneration. If the variable executive remuneration ratio is associated with Tobin's $Q$ and ROA, then this would suggest that it is effective. These two measures are considered to be more important measures of company performance than total revenue or TAs, as these are not explicitly linked to the sustainability of the company - they are considered here to be more short term in what they measure. If executive remuneration were found to be significantly related to total revenue or TAs instead of Tobin's Q or ROA, then it might be inferred that variable remuneration is incentivising the 'wrong' kind of performance, and vice versa.
In testing these hypotheses, this study therefore seeks to make a contribution by building on a long-standing and growing stream of previous literature on corporate governance in the South African context (Marcia, Maroun \& Callaghan 2015; McConvill 2005; Muchemwa, Padia \& Callaghan 2016; Nelson et al. 2011; Pendehama, Padia \& Callaghan 2017; Pududu \& De Villiers 2016; Scholtz \& Smit 2012). Having discussed the theory and empirical evidence that relates the phenomena under study, the methods applied in the research are now considered.

\section{Methods}

This section discusses data collection, data analysis, measures used and issues related to validity and reliability. Limitations are also discussed.

\section{Data collection}

For the purposes of this study, company performance was measured using the statutory annual reports of companies listed on the JSE. Thus, data used in this study were collected from the published annual reports of companies listed on the JSE Securities Exchange from 2010 to 2014. The combined list of companies listed on the JSE during 2014, a total of 352 companies were extracted from McGregor BFA. McGregor BFA, now named IRESS (2019), is a leading financial database.

Companies with insufficient information were removed from the population as part of the data screening and data transformation procedures. Although the unit of study is executive directors, their information was obtained from that reported by companies. A total of 303 companies were excluded for the following reasons: (1) their information was not available as a result of the shares being either delisted or suspended on the JSE, or (2) they did not disclose the key variable staff costs or a variable in relation to the composition of the board of directors or (3) they did not disclose information pertaining to all five of the financial years investigated. As a result, the final sample comprised 49 companies, with the final director data set containing 708 observations, each referring to a year (from 2010 to 2014), and, for each year, each of the directors of the companies in question. There are more observations for the directors than there are multiple executive directors for each company, and their data are collected for multiple years. Previous scholars, including Ismail, Yabai and Hahn (2014), Nelson et al. (2011) and Sapp (2007), have found that many companies do not have proper annual reports for a particular year, either because such reports have been removed or they are no longer available to the public. In addition, the literature indicates that some companies do not comply with a certain standard in sorting and reporting their annual reports, although they do adhere to the International Financial Reporting Standards (IFRS). In addition, some companies do not clearly distinguish between independent non-executive directors and non-independent non-executive directors on their boards nor do they explicitly specify the age, educational 
qualification or length of directorship of all directors (Ismail et al. 2014), and therefore companies with incomplete information were not included in the analysis.

\section{Data analysis}

The analysis was undertaken in three stages. Firstly, in order to answer the question as to whether there was an association between the individual components of executive director remuneration and the individual components of company performance, correlation tests were performed. Each company performance variable for each company (Tobin's Q, ROA, revenue and TAs) was tested against each executive director remuneration variable (basic salary, benefits, bonuses, retention benefits, options and total remuneration). Secondly, the association between different types (variable and fixed) components of remuneration was made explicit through the use of correlation analysis. Thirdly, to address the question as to whether there is a relationship between variable remuneration and shareholder value, fixed effects panel estimation was used to test relationships between an individual director's variable remuneration ratio and each of the four measures of company performance, net of covariance influences. IBM SPSS statistical software was used together with Stata Version 13.1 for the analysis.

\section{Measures}

Gender was measured as a binary variable. Director age and length of directorship were measured in continuous variable form, as ratio data. Measures of other variables were used as follows. Executive remuneration of directors included total cash remuneration of executive directors as disclosed in published annual reports. The variable remuneration ratio was calculated as variable remuneration (comprising benefits, annual bonuses and share options) divided by total remuneration. Total revenue was measured as sales, as disclosed in the statement of comprehensive income. Total assets were measured as non-current assets plus current assets as disclosed in the statement of the financial position of the company. Return on assets was measured as net income before extraordinary items divided by TAs, and Tobin's $Q$ as TAs at book value less common equity at book value plus common equity market value, with this total divided by the book value of TAs.

\section{Validity and reliability}

Validity was enhanced using different dependent variables with respect to firm performance. A test of the effectiveness of variable remuneration was expected to reflect different relationships with different types of company performance. All the data used were extracted from the audited and published annual reports of the companies in question; these reports are characterised by a high level of credibility and accountability. The database BFA McGregor has been used in previous studies (PWC 2013), and its use in this study also reflects precedence in the literature. Through strong reliance on precedent, the validity of the research process was strengthened.

\section{Ethical consideration}

This article followed all ethical standards for a research without direct contact with human or animal subjects.

\section{Results and discussion}

While none of the King reports stipulated a maximum size for a board (Armstrong, Segal \& Davis 2005; IOD 2009), the IOD (2009) stipulated that, in terms of King III report, a board should comprise at least two directors, namely, the $\mathrm{CEO}$ and the finance director, while the Companies Act of 2008 requires that the board of a public company should consist of at least three directors. The director matrix table compiled from the data suggests that all the firms included in the analysis should meet this criterion. In total, 167 executive directors and 49 firms were included in this study. Table 1 reports descriptive statistics for remuneration types. The panel data set includes repeated observations over time. The descriptive data on the executive director characteristics are pooled and reported over the period of this study.

Table 1 shows that, on average, the basic salary of directors per director-year was R2 570 111. In spite of the fact that there were significant variations in basic salary between the director-years, this item demonstrated the highest level of agreement across the director-years (coefficient of variation $[C V]=0.660$ ). All the other items on the list varied extensively with retention bonuses displaying the highest variation $(C V=5.230)$. As noted from the data, not all the companies paid a retention bonus. Furthermore, not all the companies had options that were disclosed at face value and thus a significant variation was also noted in this category $(\mathrm{CV}=3.8)$. These also differed from company to company although this category displayed marginal variation only $(\mathrm{CV}=3.573)$. Table 2 reports descriptive statistics relating to company performance. Company performance is the dependent variable, and the descriptive statistics report is pooled by year in Table 2 .

Table 2 shows the mean amounts for all the variables examined, namely, revenue, TAs, Tobin's $Q$ and ROAs. The highest variation in revenue occurs during 2012, and CVs show a trend towards stabilisation over 2013 and 2014. The 2010 revenue has the lowest variation $(C V=1.9833)$. Coefficient of variations for TAs, Tobin's $Q$ and ROA are fairly consistent across the periods, with the highest variation during $2013(\mathrm{CV}=3.4485)$ and the lowest during 2010 $(\mathrm{CV}=2.3297)$.

TABLE 1: Descriptive statistics: Executive remuneration.

\begin{tabular}{lccccc}
\hline Variable & Minimum & Maximum & Mean & SD & CV \\
\hline Basic salary & 0 & 15303000 & 2570111 & 1697410 & 0.660 \\
Benefits & 0 & 56724000 & 687229.6 & 2455689 & 3.573 \\
Bonuses & 0 & 30616000 & 1711096 & 2470612 & 1.444 \\
Retention & 0 & 3127000 & 66037.65 & 345351.6 & 5.230 \\
Options & 0 & 52954000 & 849786.7 & 3228832 & 3.800 \\
\hline Total & $\mathbf{0}$ & $\mathbf{6 8 6 3 6 0 0 0}$ & $\mathbf{5 8 8 4 2 6 1}$ & $\mathbf{6 3 1 9 5 2 1}$ & $\mathbf{1 . 0 7 4}$ \\
\hline
\end{tabular}

$\mathrm{CV}$, coefficient of variation (ratio of standard deviation to absolute mean); SD, standard deviation. 
TABLE 2: Descriptive statistics: Company performance.

\begin{tabular}{|c|c|c|c|c|c|}
\hline Variable & Minimum & Maximum & Mean & SD & CV \\
\hline Revenue_2010 & 53438000 & 122000000000 & 11400000000 & 22600000000 & 1.9833 \\
\hline Revenue_2011 & 55608000 & 1110000000000 & 34800000000 & 159000000000 & 4.5774 \\
\hline Revenue_2012 & 47382983 & 1260000000000 & 39500000000 & 180000000000 & 4.5587 \\
\hline Revenue_2013 & 92382000 & 170000000000 & 15300000000 & 31300000000 & 2.0434 \\
\hline Revenue_2014 & 104000000 & 203000000000 & 16700000000 & 34600000000 & 2.0763 \\
\hline TobinsQ_2010 & 0.1 & 1.2 & 0.537 & 0.2249 & 2.3297 \\
\hline TobinsQ_2011 & 0.1 & 1 & 0.524 & 0.2106 & 3.0728 \\
\hline TobinsQ_2012 & 0 & 1 & 0.518 & 0.2039 & 3.2010 \\
\hline TobinsQ_2013 & 0.1 & 6.1 & 0.615 & 0.8226 & 3.4485 \\
\hline TobinsQ_2014 & 0.1 & 5.3 & 0.594 & 0.7129 & 3.3818 \\
\hline ROA_2010 & -15.01 & 81.49 & 13.6922 & 15.90071 & 2.3297 \\
\hline ROA_2011 & -33.48 & 74.73 & 11.1294 & 15.58976 & 3.0728 \\
\hline ROA_2012 & -26.99 & 78.42 & 10.168 & 14.45553 & 3.2010 \\
\hline ROA_2013 & -35.11 & 65.61 & 7.8288 & 15.6237 & 3.4485 \\
\hline ROA_2014 & -20.66 & 68.76 & 8.6355 & 13.98694 & 3.3818 \\
\hline TotalAssets_2010 & 34223000 & 156000000000 & 10200000000 & 23700000000 & 2.3297 \\
\hline TotalAssets_2011 & 36533000 & 342000000000 & 17600000000 & 54200000000 & 3.0728 \\
\hline TotalAssets_2012 & 45698000 & 397000000000 & 19500000000 & 62300000000 & 3.2010 \\
\hline TotalAssets_2013 & 51716000 & 561000000000 & 25000000000 & 86100000000 & 3.4485 \\
\hline TotalAssets_2014 & 59021000 & 611000000000 & 27900000000 & 94400000000 & 3.3818 \\
\hline
\end{tabular}

Note: Values in these tables are in South African rands.

ROA, return on assets; CV, coefficient of variation; SD, standard deviation.

Panel data analysis is therefore used here in order to exploit variance across firms and directors to test relationships across time. Given these choices, the first approach was taken as the most appropriate for bivariate tests of association to test Hypothesis 1, and the third as most appropriate to test Hypothesis 2. The bivariate tests results are reported and discussed as follows.

\section{Relationships between performance measures}

Spearman's (non-parametric) Rho tests were used to test the bivariate associations between the variables of interest. This test was chosen, as it was robust to non-normality in variable distributions. Knowledge of the zero-order correlational structure was taken to provide important insights into the net relationships between variables. As shown in Table 3, which reports correlations between different performance types, only the association between revenue and TAs is significant at within the $5 \%$ level of significance. These results are in accordance with literature that treats these indicators differently, supporting the decision in this study to use them as separate indicators of performance. Table 4 reports the correlation matrix for the types of benefits.

\section{Relationships between remuneration types}

The association between basic salary and bonuses is the strongest of the tested variables (Table 4), followed by that between benefits and options. This suggests that basic salary and bonuses share $0.28 \%$ of their variance, almost a third. Table 5 reports the correlations for these remuneration types with measures of performance. Having reported on the relationships between performance measures and between remuneration types, the testing of Hypothesis 1 is now reported and discussed.
TABLE 3: Correlation matrix for performance types.

\begin{tabular}{|c|c|c|c|c|c|}
\hline Variable & Spearman's rho & Revenue & $\begin{array}{c}\text { Total } \\
\text { assets }\end{array}$ & Tobin's Q & $\begin{array}{c}\text { Return on } \\
\text { assets }\end{array}$ \\
\hline \multirow[t]{2}{*}{ Revenue } & Correlation coefficient & 1 & - & - & - \\
\hline & Sig. (2-tailed) & - & - & - & - \\
\hline \multirow[t]{2}{*}{ Total assets } & Correlation coefficient & $0.8856 *$ & 1 & - & - \\
\hline & Sig. (2-tailed) & 0.0001 & - & - & - \\
\hline \multirow[t]{2}{*}{ Tobin's Q } & Correlation coefficient & -0.2298 & -0.2500 & 1 & - \\
\hline & Sig. (2-tailed) & 0.1084 & 0.0852 & - & - \\
\hline \multirow{2}{*}{$\begin{array}{l}\text { Return on } \\
\text { assets }\end{array}$} & Correlation coefficient & 0.0130 & 0.0070 & 0.1400 & 1 \\
\hline & Sig. (2-tailed) & 0.9260 & 0.9600 & 0.3450 & - \\
\hline
\end{tabular}

Sig., significance.

*, Correlation is significant at the 0.01 level (2-tailed).

Hypothesis 1. Remuneration will be significantly associated with short-term measures of performance.

Table 5 reports correlations between the four different measures of firm performance and the five measures of remuneration. Revenue is positively and significantly associated with all the bonus types other than retention. However, the strongest association with revenue is for basic salary, which reflects a shared variance of $18.4 \%$, suggesting that shared variance between these two measures is less than $20 \%$. For revenue and benefits, shared variance is $10.1 \%$, bonuses about $3 \%$ and options $1.4 \%$. Shared variances show the relative importance of these types of revenue for each of the firm outcome types. In terms of the tested hypothesis, basic salary is positively associated with revenue and TAs. This is as expected, because this is typically not a variable component of remuneration. Remuneration of this nature is expected to be of little value in checking the incentives executives have to expand their scope of influence or the size of the firm (Baumol 1959). Benefits also seem to be underutilised in their support of the real value of the firm measure, as these are not significantly associated with Tobin's Q. It is possible that benefits are treated in a similar 
TABLE 4: Correlation matrix for remuneration types.

\begin{tabular}{|c|c|c|c|c|c|c|c|}
\hline Variable & Spearman's rho & Basic salary & Benefits & Bonuses & Retention & Options & Total \\
\hline \multirow[t]{2}{*}{ Basic salary } & Correlation coefficient & 1 & - & - & - & - & - \\
\hline & Sig. (2-tailed) & - & - & - & - & - & - \\
\hline \multirow[t]{2}{*}{ Benefits } & Correlation coefficient & $0.434^{* *}$ & 1 & - & - & - & - \\
\hline & Sig. (2-tailed) & 0 & - & - & - & - & - \\
\hline \multirow[t]{2}{*}{ Bonuses } & Correlation coefficient & $0.525^{* *}$ & $0.268 * *$ & 1 & - & - & - \\
\hline & Sig. (2-tailed) & 0 & 0 & - & - & - & - \\
\hline Retention & Sig. (2-tailed) & 0.188 & 0.963 & 0.023 & - & - & - \\
\hline \multirow[t]{2}{*}{ Options } & Correlation coefficient & $0.180 * *$ & $0.231 * *$ & $0.162 * *$ & $-0.084 *$ & 1 & - \\
\hline & Sig. (2-tailed) & 0 & 0 & 0 & 0.025 & - & - \\
\hline
\end{tabular}

Sig., significance.

*, Correlation is significant at the 0.05 level (2-tailed).

**, Correlation is significant at the 0.01 level (2-tailed).

TABLE 5: Correlations between remuneration and performance measures.

\begin{tabular}{lcccc}
\hline Variable & Revenue & Total assets & Tobin's Q & ROA \\
\hline Basic salary & $0.429 * *$ & $0.428^{* *}$ & $-0.229 * *$ & 0.024 \\
Sig. (2-tailed) & 0 & 0 & 0.526 & - \\
Benefits & $0.318^{* *}$ & $0.249 * *$ & -0.015 & -0.061 \\
Sig. (2-tailed) & 0 & 0.686 & 0.106 & - \\
Bonuses & $0.176^{* *}$ & $0.265^{* *}$ & $-0.196^{* *}$ & 0.028 \\
Sig. (2-tailed) & 0 & 0 & 0.455 & - \\
Retention & 0.022 & $-0.077^{*}$ & $-0.109 * *$ & $-0.158^{* *}$ \\
Sig. (2-tailed) & 0.042 & 0.004 & 0 & - \\
Options & $0.119 * *$ & $0.141^{* *}$ & 0.004 & 0.065 \\
Sig. (2-tailed) & 0 & 0.913 & 0.085 & - \\
\hline
\end{tabular}

ROA, return on assets; Sig., significance.

*, Correlation is significant at the 0.05 level (2-tailed).

**, Correlation is significant at the 0.01 level (2-tailed).

way to basic salary. Of concern, however, is that bonuses seem to also have the same effect. Bonuses might be treated in the same way as basic salary. Even more concerning is the positive association between options and the gross 'size' indicators of company performance, revenue and TAs. From these results, it would seem that variable components of remuneration are not being effectively used to improve the value of a firm, or to improve measures such as Tobin's Q, but are largely contributing to revenue or TAs growth instead. Of note is the negative association between the use of retention bonuses, which not only are negatively associated with the value of the firm values of Tobin's $Q$ as well as ROAs, but are also negatively, albeit weakly, associated with TAs and not associated with revenue. It is possible that the use of retention bonuses can reduce value in this context.

Tobin's Q, as the ratio of market value of the firm's assets (including outstanding stock and debt) to replacement cost of the firm's assets (book value), is essentially a measure of the worth of the company, and its negative associations with basic salary, bonuses and retention incentives suggest that executive remuneration structures are at odds with this measure of firm value. These results suggest that remuneration strategies may be more aligned with revenue generation, a shorter term outcome, and with asset generation, without sufficient regard to replacement costs of these assets. These results seem to be consistent with Baumol's (1959) prediction that executives will tend to maximise sales revenues, subject to a minimum profit constraint; the implication is that revenue generation can be a primary goal, reflected in remuneration choices.

The strong associations between asset growth and all the remuneration types except for retention bonuses also reflects long-standing predictions (Baumol 1959; Marris 1964; Williamson 1963) that executives will tend to maximise growth of the firm, rather than its net value or profitability. It would seem the remuneration strategy reflected in this analysis supports this focus, with negative consequences for firm value. This is not the full story, however, as the firm strategies reflected in this analysis are dominated by firms with more directors and the analysis of correlations does not take into account covariate influences such as age, gender and length of directorship. Nevertheless, the analysis provides enough information to support Hypothesis 1 that remuneration is more strongly associated with short-term measures of performance, and the alternative hypothesis is rejected. The results of the testing of Hypothesis 2 are now reported and discussed.

Hypothesis 2. The variable executive remuneration ratio is positively and significantly associated with firm performance.

Although bivariate correlations provided some evidence of the net associations between remuneration types and firm performance, what was not clear from this analysis is the extent to which the variable component of remuneration contributes to each of the outcome measures. The nonvariable remuneration component was taken to include basic salary and benefits, and the variable component included bonuses, retention bonuses and options. The variable component as a proportion of total remuneration was tested as a predictor of each of the four measures of firm performance. Age, gender and length of directorship were included as covariate factors, in order to obtain a test of the contribution of the variable pay component to performance over and above the influence of these variables. Initial Ordinary Least Squares (OLS) models were used to test for multicollinearity. Variance inflation factors were low, suggesting little threat to the interpretation of results owing to multicollinearity. The following specification was developed for testing using fixed effects panel data estimation. 
$\xi_{i t}=a_{i}+\beta_{1}$ Age $_{i t}+\beta_{2}$ Gender $_{i}+\beta_{3}$ Length of directorship $_{i t}+\beta_{4}$ Variable payratio $_{i t}+u_{i t}$

In this specification, $\xi_{i t}$ represents each of the four dependent variables in each of the four tested models, namely ROA, total revenue, Tobin's $Q$ and TAs. Age, gender and length of directorship are included as covariates together with the variable pay ratio. Panel data estimation was used because OLS estimations have been shown to be subject to heterogeneity bias, whereby the idiosyncratic variance associated with individual units can bias results. In contrast, panel estimation can remove idiosyncratic variance associated with between unit effects as well as unobserved influences that are constant over time, and can address heterogeneity bias by using within-unit variance. The use of fixed effects is especially important, given significant industry differences in relationships between corporate governance and performance - fixed effects that take into account these differences between firms, at the firm level. Another problem with the pooled OLS estimations is the unbalanced nature of the sample, with an overrepresentation of the results of directors who have had a higher tenure. Fixed-effects panel estimations were therefore taken to remedy these deficiencies.

Results of the fixed-effects panel tests are shown in Table 6 . According to the fixed-effects panel estimations, the age of a director is negatively associated with revenue. Length of the directorship, however, is positively associated with revenue. Given the low multicollinearity in the model, which suggests that this relationship is not an artefact of multicollinearity, this might suggest that younger directors or those with longer tenure are more likely to be found in firms with higher revenue.

The variable of interest, namely, the variable pay ratio, is strongly and negatively associated with revenue, and is also weakly and negatively associated with TAs. Variable pay is positively but weakly associated with Tobin's Q. Variable pay is negatively associated with revenue and TAs; results

TABLE 6: Results of fixed effects panel estimations: Determinants of performance.

\begin{tabular}{lcccc}
\hline Variables & $\begin{array}{c}(\mathbf{1}) \\
\text { Return on assets }\end{array}$ & $\begin{array}{c}(\mathbf{2}) \\
\text { Revenue }\end{array}$ & $\begin{array}{c}\text { (3) } \\
\text { Tobin's Q }\end{array}$ & $\begin{array}{c}\text { (4) } \\
\text { Total assets }\end{array}$ \\
\hline Age & -3.053 & $-6.519 \mathrm{e}+11^{* *}$ & -0.0774 & $-1.151 \mathrm{e}+10$ \\
& $(7.019)$ & $(2.373 \mathrm{e}+10)$ & $(0.0706)$ & $(2.725 \mathrm{e}+10)$ \\
Gender (male) & - & - & - & - \\
Length of & 1.458 & $6.541 \mathrm{e}+11^{* *}$ & 0.0664 & $1.738 \mathrm{e}+10$ \\
directorship & $(7.042)$ & $(2.381 \mathrm{e}+10)$ & $(0.0708)$ & $(2.734 \mathrm{e}+10)$ \\
Variable pay ratio & 0.577 & $-9.530 \mathrm{e}+09^{* *}$ & $0.0179 *$ & $-6.543 \mathrm{e}+09 *$ \\
& $(0.964)$ & $(3.260 \mathrm{e}+09)$ & $(0.00969)$ & $(3.743 \mathrm{e}+09)$ \\
Constant & 150.3 & $2.706 \mathrm{e}+13^{* *}$ & 3.857 & $4.598 \mathrm{e}+11$ \\
& $(291.5)$ & $(9.855 \mathrm{e}+11)$ & $(2.931)$ & $(1.132 \mathrm{e}+12)$ \\
Observations & 309 & 309 & 309 & 309 \\
$R$-squared & 0.061 & 0.842 & 0.059 & 0.061 \\
$\begin{array}{l}\text { Number of } \\
\text { directors }\end{array}$ & 153 & 153 & 153 & 153 \\
\hline
\end{tabular}

Standard errors in parentheses.

$*, p<0.1 ; * *, p<0.01$. suggest that variable pay may be effective in reducing a focus on revenue or total assets, and might contribute to profitability measures such as Tobin's Q in this context.

While according to the bivariate results, the strong linkages between asset growth and all the remuneration types, except for retention bonuses, support the notion that executives would tend to maximise the growth of the firm rather than its net value or profitability (Baumol 1959; Marris 1964; Williamson 1963), the more precise panel results suggest that the greater the variable component of executive remuneration, the less an indiscriminate focus on revenue seems to result. Given that the panel results show relationships that are robust to heterogeneity bias, these results are taken to provide richer information value than the correlation tests.

The principal-agent and moral hazard problems are both at the heart of the corporate governance debate and there is a need for separation of ownership and control in firms, according to the agency theory (Jensen \& Meckling 1976). The weak but significant relationship between variable pay and Tobin's Q, as well as its negative relationship with both TAs and gross revenue, therefore supports agency theory predictions that variable, or contingent remuneration, can be used to align the interests of owners to those of the directors employed by shareholders who are tasked to manage and control a company's resources on behalf of shareholders (Amess \& Drake 2003).

These findings seem to suggest that variable remuneration might be effective, notwithstanding concerns that executives themselves might often have control of the design of their remuneration (Forbes \& Watson 2012). The direction of causality predicted by theory originates from the design of remuneration towards the type of firm performance, and the measures of performance seem to differentiate well between those associated with shareholder value and those that might be more associated with 'empire building' or growth that might be associated with executive prestige and control of resources but at the expense of shareholder value. Previous research (De Wet 2012; Scholtz \& Smit 2012) has shown that Tobin's Q and ROA are good measures of company performance, as they reflect value added to shareholders. Although no relationship is found between variable payment and ROAs, the findings here are nonetheless taken to suggest that variable pay may be useful in constraining the 'empire building' of managers (Baumol 1959; Marris 1964; Williamson 1963), or the pursuit of growth in revenue or assets without a focus on maximising returns to shareholders.

These findings also differ from those in the international context, such as McConvill (2005), Gregg et al. (2010), and Girma et al. (2013), who found little evidence of a relationship between executive remuneration and company performance, albeit across contexts other than this one. These findings also contrast with research in the South African context, such as that of Bradley (2013) who found no correlation between CEO compensation and company performance. 
These findings are, however, in accordance with previous research in other contexts, such as that by Conyon (1997) and Merhebi et al. (2006) who found executive pay to be directly proportional to current shareholder returns, and with other research in the South African context that has found evidence of a relationship between executive remuneration and performance indicators for companies listed on the AltX (Scholtz \& Smit 2012) and on the JSE (De Wet 2012). Notwithstanding the mixed results of previous research, these findings suggest that variable pay can produce outcome effects aligned to shareholder value.

These results are considered particularly important given the debate on executive remuneration and company performance in South Africa, the backdrop to which is evidence of the widening income inequality between executives and ordinary workers in South African companies (Theku 2014). Having presented the findings of this study, recommendations for practice and for further research are now discussed.

\section{Limitations}

Data were limited to that of those JSE companies for which all financial and non-financial information were available for all the years in the period under investigation. The sample may therefore represent companies that report more fully on their operations, capturing many of the top performing companies on the JSE. Further research should seek to extend this study over time as data from company reporting improve. This study suffers from similar limitations of much of the work that it builds on. In spite of this, the data set is unique in that it is hand-collected, offering useful insights that build on previous studies. Future research should extend this work to the present day. The results of this study are important, notwithstanding these limitations, as they offer a test of whether variable remuneration is associated with the 'right' types of performance. This is an important test of seminal theory in this context, which further research could build on. Certain further limitations relate to the delimitations of the work.

\section{Delimitations}

The scope of the work was subject to certain further delimitations. Firstly, this research did not aim to study any company other than those listed on the JSE. Secondly, this study did not aim to investigate the remuneration packages of any other directors besides executive directors. Further research, particularly of a qualitative nature, is recommended, in order to unearth causal influences that statistical testing cannot.

\section{Recommendations for practice and further research}

Given the positive relationship between variable pay and Tobin's Q, and its negative relationships with both gross revenue and TAs, the efficacy of variable pay is supported in this context. The lack of an association between variable pay and ROAs is notable, however. Remuneration schemes should be tailored to ensure more of a focus on ROAs. Company remuneration policies should be informed by evidence-based approaches, so as to reduce the dominance of basic pay as a component of remuneration, particularly if this dominance is found to reduce the focus on shareholder maximisation by managers. It is acknowledged that the consideration of employee motivation, and the contribution of basic pay to this, is beyond the scope of this work. Nevertheless, based on these findings, companies should use an evidence-based rationale to determine the most effective variable pay ratio, so as to ensure alignment of remuneration to shareholder value creation, as variable pay ratios can be effective in this regard. Further research would do well to investigate the moderator and mediator effects of variable remuneration on company performance in this context, and qualitative research is recommended, in order to provide the groundwork for further empirical work. Overall, given the contribution of King III report to improved corporate governance (IOD 2009) in South Africa, it is possible that the results in support of the influence of variable pay in this context over this period may also reflect the influence of a new reporting climate that is in no small part owing to these governance innovations.

\section{Acknowledgements Competing interests}

The authors have declared that no competing interest exists.

\section{Authors' contributions}

M.N. and N.P. conceptualised and developed this work. C.W.C. wrote the workup for publication and performed additional statistical analysis.

\section{Funding information}

This research received no specific grant from any funding agency in the public, commercial or not-for-profit sectors.

\section{Data availability statement}

The data used in this article are from publicly available sources. No survey or new data were created in this study.

\section{Disclaimer}

The views and opinions expressed in this article are those of the authors and do not necessarily reflect the official policy or position of any affiliated agency of the authors.

\section{References}

Amadeo, K., 2017, 'The 2008 financial crisis', The Balance, viewed 04 December 2017, from https://www.thebalance.com/2008-financial-crisis-3305679.

Amess, K. \& Drake, L., 2003, Executive remuneration and firm performance: Evidence from a panel of mutual organisations, viewed 30 November 2015, from http:// www.le.ac.uk/economics/research/RePEc/lec/leecon/dp03-13.pdf.

Armstrong, P., Segal, N. \& Davis, B., 2005, 'Corporate governance: South Africa, a pioneer in Africa', The South African Institute of International Affairs: Global Best Practice 1, 1-39. 
Baumol, W., 1959, Business behaviour, value and growth, Harcourt Brace Jovanovich, New York.

Bradley, S., 2013, 'The relationship between CEO compensation and company performance in a South African context', Journal of Economic and Financial Sciences 6(3), 539-564. https://doi.org/10.4102/jef.v6i3.247

Colvin, G., 2008, 'AmEx gets CEO pay right', Fortune 21, 12-13.

Conyon, M.J., 1997, 'Corporate governance and executive compensation', International Journal of Industrial Organization 15(4), 493-509. https://doi.org/ 10.1016/S0167-7187(96)01032-6

Deloitte, 2014, Disclosure of remuneration: A hot topic, viewed 04 November 2015, from http://www2.deloitte.com/content/dam/Deloitte/za/Documents/governance-riskcompliance/ZA_DisclosureOfRemunerationAHotTopic_04042014.pdf.

De Wet, J.H. 2012, 'Executive compensation and the EVA and MVA performances of South African listed companies', South African Business Review 16(3), 57-80.

Fernandes, N., 2005, Board compensation and firm performance: The role of 'Independent' board members, viewed 30 November 2015, from http://www.fep. up.pt/conferencias/pfn2006/conference\%20papers/606.pdf.

Forbes, W. \& Watson, R., 2012, 'Managerial remuneration and corporate governance: A review of the issues, evidence and Cadbury Committee proposals', Accounting and Business Research 23(1), 331-338. https://doi.org/10.1080/00014788.1993. 9729901

Girma, S., Thompson, S. \& Wright, P.W., 2003, Corporate governance reform and executive compensation determination: Evidence from the UK viewed 15 November 2013, from http://web.warwick.ac.uk/res2003/papers/ Thompsons.pdf.

Gregg, P., Jewell, S. \& Tonks, I., 2010, Executive pay and performance in the UK, AXA Working Paper Series 5, Discussion Paper no. 657, viewed 05 December 2015, from http://www.lse.ac.uk/fmg/workingPapers/discussionPapers/DP657_2010 ExecutivePayandPerformanceintheUK.pdf.

Ingham, H. \& Thompson, S., 2012, 'Executive compensation and deregulation in UK building societies', Accounting and Business Research 23(1), 373-383. https://doi. org/10.1080/00014788.1993.9729905

Institute of Directors of South Africa (IOD), 2009, King III report, viewed 12 December 2014, from http://www.iodsa.co.za/?page=Kinglll.

IRESS, 2019, 'IRESS expert', viewed 24 November 2019, from https://expert.inetbfa. com/\#Logon.

Ismail, S.B., Yabai, N.V. \& Hahn, L.J., 2014, 'Relationship between CEO pay and firm performance: Evidence from Malaysia listed firms', Journal of Economics and Finance 3(6), 14-31. https://doi.org/10.9790/5933-0361431

Jensen, M. \& Meckling, W., 1976, 'Theory of the firm: Managerial behaviour, agency costs and ownership structure', Journal of Financial Economics 3(4), 305-360. https://doi.org/10.1016/0304-405X(76)90026-X

Kyereboah-Coleman, A. \& Biekpe, N., 2005, Corporate governance and the performance of microfinance institutions (MFIs) in Ghana, Working paper, UGBS, Legon.

Main, B.G.M. \& Johnston, J., 2012, 'Remuneration committees and corporate governance', Accounting and Business Research Journal 23(1), 351-362. https:// doi.org/10.1080/00014788.1993.9729903

Maradi, M.M., Navi, B.S. \& Dasar, P., 2015, 'Corporate governance practices in selected co-operative banks at Vijayapur City', Journal of Business and Management 17(3) $45-53$.

Marcia, A., Maroun, W. \& Callaghan, C.W., 2015, 'Value relevance and corporate responsibility reporting in the South African context: An alternative view post King-III', South African Journal of Economic and Management Sciences 18(4), 500-518. https://doi.org/10.4102/sajems.v18i4.1192

Marris, R., 1964, The economic theory of managerial capitalism, Macmillan, London.
McConvill, J., 2005, 'Positive corporate governance and its implications for executive compensation' German Law Journal 6(12), 1777-1805. https://doi.org/10.1017/ S2071832200004314

Merhebi, R., Pattenden, K., Swan, P. \& Zhou, X., 2006, 'Australian chief executive officer remuneration pay and performance', Accounting and Finance 46, 481-497. https://doi.org/10.1111/j.1467-629X.2006.00178.x

Muchemwa, M.R., Padia, N. \& Callaghan, C.W., 2016, 'Board composition, board size and financial performance of Johannesburg Stock Exchange companies', South African Journal of Economic and Management Sciences 19(4), 497-513. https:// doi.org/10.4102/sajems.v19i4.1342

Nelson, J., Gallery, G. \& Reza, P., 2011, 'The impact of corporate governance on CEO remuneration structures in the aftermath of the GFC', paper presented at the 2011 Accounting and Finance Association of Australia and New Zealand conference, viewed 15 November 2013, from http://www.afaanz.org/openconf/2011/ modules/request.php?module=oc_proceedingsandaction=view.phpanda=Accept +as+Paperandid $=220$

Otten, J., 2007, Theories on executive pay: A literature overview and critical assessment, Working paper, Rotterdam School of Management, Rotterdam.

Pendehama, V., Padia, N. \& Callaghan, C.W., 2017, 'Audit fee premium: The potential effect of King III', South African Journal of Accounting Research 31(2), 83-101. https://doi.org/10.1080/10291954.2016.1144867

Pududu, M.L. \& De Villiers, C., 2016, 'Earnings management through loss avoidance: Does South Africa have a good story to tell?', South African Journal of Economic and Management Sciences 19(1), 18-38. https://doi.org/10.4102/sajems.v19i1.1124

PWC, 2013, Executive directors' fees and remuneration: Practices and trends report South Africa, July, viewed 04 December 2017, from https://www.pwc.co.za/en/ assets/pdf/executive-directors-report-2013.pdf.

Sanda, A., Mikailu, A.S. \& Garba, T., 2008, 'Board independence and firm financial performance: Evidence from Nigeria', in Centre for the Study of African Economies (CSAE) conference, Oxford, March 16.

Sapp, S.G., 2007, 'The impact of corporate governance on executive compensation', European Financial Management 14(4), 710-746. https://doi.org/10.1111/ j.1468-036X.2008.00443.x

Scholtz, H.E. \& Smit, A., 2012, 'Executive remuneration and company performance for South African companies listed on the Alternative Exchange (AltX)', South African Business Review 16(1), 22-38.

Sheng, A., 2000, 'Transparency, accountability and standards in global markets', in Proceedings of the OECD 2nd Asian Roundtable on Corporate Governance, viewed 28 November 2015, from http://www.oecd.org/dataoecd/6/30/1930855.pdf.

Shleifer, A. \& Vishny, R.W., 1997, 'A survey of corporate governance', The Journal of Finance L2(2), 737-783. https://doi.org/10.1111/j.1540-6261.1997.tb04820.x

Tariq, U., 2010, CEO compensation: Relationship with performance and influence of board of directors, viewed 25 November 2015, from http://www.diva-portal.org/ smash/get/diva2\%3A351913/FULLTEXT01.pdf.

Theku, M., 2014, CEO compensation sensitivity performance in the South African mining industry, viewed from http://repository.up.ac.za/bitstream/handle/2263/ 43997/Theku_CEO_2014.pdf? sequence=1\&isAllowed =y.

Tshipa, J., Brummer, L.M., Wolmarans, H. \& Du Toit, E., 2018, 'The effect of industry nuances on the relationship between corporate governance and financial performance: Evidence from South African listed companies', South African Journal of Economic and Management Sciences 21(1), 1-18. https://doi. org/10.4102/sajems.v21i1.1964

World Economic Forum (WEF), 2018, The Global Competitiveness Report 2018, World Economic Forum, viewed 06 March 2020, from https://www.weforum.org/reports/ the-global-competitveness-report-2018.

Williamson, O.E., 1963, 'Managerial discretion and business behaviour', American Economic Review 53(5), 1032-1057. 